This is the author's final, peer-reviewed manuscript as accepted for publication. The publisher-formatted version may be available through the publisher's web site or your institution's library.

\title{
Syntheses, neural protective activities, and inhibition of glycogen synthase kinase- $3 \beta$ of substituted quinolines
}

Jianyu Lu, Izumi Maezawa, Sahani Weerasekara, Ramazan Erenler, Tuyen D. T. Nguyen, James Nguyen, Luxi Z. Swisher, Jun Li, Lee-Way Jin, Alok Ranjan, Sanjay K. Srivastava, and Duy $\mathrm{H}$. Hua

\section{How to cite this manuscript}

If you make reference to this version of the manuscript, use the following information:

Lu, J., Maezawa, I., Weerasekara, S., Erenler, R., Nguyen, T. D. T., Nguyen, J., ... Hua, D. H. (2014). Syntheses, neural protective activities, and inhibition of glycogen synthase kinase-3 $\beta$ of substituted quinolones. Retrieved from http://krex.ksu.edu

\section{Published Version Information}

Citation: Lu, J., Maezawa, I., Weerasekara, S., Erenler, R., Nguyen, T. D. T., Nguyen, J., ... Hua, D. H. (2014). Syntheses, neural protective activities, and inhibition of glycogen synthase kinase-3 $\beta$ of substituted quinolones. Bioorganic \& Medicinal Chemistry Letters, 24(15), 3392-3397.

Copyright: (C) 2014 Elsevier Ltd.

Digital Object Identifier (DOI): doi:10.1016/j.bmcl.2014.05.085

Publisher's Link:

http://www.sciencedirect.com/science/article/pii/S0960894X14005940

This item was retrieved from the K-State Research Exchange (K-REx), the institutional repository of Kansas State University. K-REx is available at http://krex.ksu.edu 


\title{
Syntheses, Neural Protective Activities, and Inhibition of Glycogen Synthase Kinase-3 $\beta$ of Substituted Quinolines
}

\author{
Jianyu Lu, ${ }^{\text {a } I z u m i ~ M a e z a w a, ~}{ }^{\mathrm{b}}$ Sahani Weerasekara, ${ }^{\mathrm{a}}$ Ramazan Erenler, ${ }^{\mathrm{a}}$ Tuyen D. T. Nguyen,

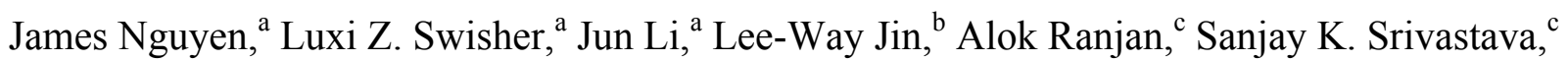 \\ and Duy H. Hua*,a
}

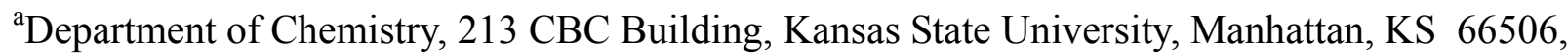
United States

${ }^{\mathrm{b}}$ M.I.N.D. Institute and Department of Pathology, $282550^{\text {th }}$ Street, UC Davis Health System, Sacramento, California 95817, United States

${ }^{\mathrm{c}}$ Department of Biomedical Sciences and Cancer Biology Center, Texas Tech University Health Sciences Center, Amarillo, Texas 79106, United States

* Corresponding author. Tel.: +1 (785) 532 6699; fax: +1 (785) 5326666.

E-mail address: duy@ksu.edu (D.H. Hua).

Key words: Alzheimer's disease, amyloid $\beta$, glycogen synthase kinase- $3 \beta$, neural protective activity, protein kinase $\mathrm{C}$, quinolines.

\begin{abstract}
.
A new series of fifteen 5-, 6-, and 8-appended 4-methylquinolines were synthesized and evaluated for their neural protective activities. Selected compounds were further examined for

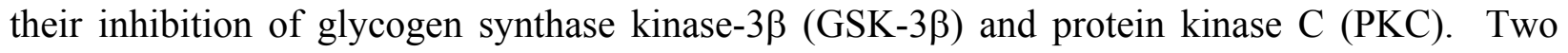


most potent analogs, compounds $\mathbf{3}$ and 10, show nanomolar protective activities in amyloid $\beta$ induced MC65 cells and enzymatic inhibitory activities against GSK-3 $\beta$, but poor PKC inhibitory activities. Using normal mouse model, the distribution of the most potent analog 3 in various tissues and possible toxic effects in the locomotors and inhibition of liver transaminases activities were carried out. No apparent decline of locomotor activity and no inhibition of liver transaminases were found. The compound appears to be safe for long-term use in Alzheimer's disease mouse model.

Alzheimer's disease (AD), a progressive neurodegenerative disorder, is the most common form of dementia in the elderly. ${ }^{1} \mathrm{AD}$ brains have three major lesions, (1) formation of aggregates and plaques of amyloid- $\beta$ (A $\beta$ ) peptide, a 39-43 residue protein, outside of neurons; (2) formation of abnormal neurofibrillary tangles (NTFs) consists of hyperphosphorylated tau protein inside the neurons; and (3) dysfunction of neurons including cholinergic, noradrenergic, serotonergic and pyramidal neurons. ${ }^{2}$ Major strategies for experimental disease-modifying therapies include targeting multiple sites in $A \beta$ metabolism (A $\beta$ synthesis, aggregation, deposition and clearance), targeting tauopathy (modulation of tau phosphorylation and inhibition of tau aggregation), regulating cholesterol homeostasis, anti-excitotoxicity, anti-inflammation and modulating calcium homeostasis, among others. ${ }^{1-3}$ A number of compounds has shown efficacy in $\mathrm{AD}$ transgenic mouse models, ${ }^{4-12}$ but their efficacy in $\mathrm{AD}$ patients remains uncertain. Moreover, several drug candidates in clinical trials failed to show benefits. ${ }^{1-3}$ In our pursuit of finding neural protective compounds for $\mathrm{AD}$, we use MC65 cells protection assay as our primary screen for bioactive compounds, ${ }^{13-15}$ and a class of quinolines containing various substituents (Figure 1) were found to have submicromolar activities. MC65 cells assay generates few false 
positive results and identifies leads that penetrate cells and ameliorate $\mathrm{A} \beta$ oligomer-induced toxicity. ${ }^{13}$ Moreover, studies of the enzyme assay inhibition of glycogen synthase kinase-3 $\beta$ (GSK-3 $\beta$ ) revealed several quinoline molecules inhibited the enzyme in nanomolar ranges. GSK-3 $\beta$ is abundant in neurons of the central nervous system and catalyzes the phosphorylation of tau proteins, which are overexpressed in AD brains. ${ }^{16}$ Hyperphosphorylation of tau proteins in brain from imbalanced activity of GSK-3 $\beta$ results in neurofibrillary tangles and leads to cell death. ${ }^{16-18}$ Moreover, the "dual pathway" hypothesis ${ }^{19}$ suggests that GSK-3 affects both hyperphosphorylation of tau and elevation of $A \beta$ via the enhancement of enzymatic processing of APP. A dual effect of reduction of A $\beta$ toxicity and inhibition of GSK-3 $\beta$ may provide a greater beneficial effect than conventional GSK-3 $\beta$ inhibitors and anti-A $\beta$ molecules. ${ }^{20}$ Herein, we reported the syntheses of quinolines $\mathbf{2}$ - 16 (Figure 1) and evaluation of their bioactivities along with our previously reported quinoline $1 .{ }^{21}$ Several compounds possess dual effects of inhibition of A $\beta$ toxicity in MC65 cells and GSK-3 $\beta$ enzyme. 
Figure 1. Synthesized and bioevaluated quinolines 1 - 16.<smiles>COc1cc(NCCCN)c2nccc(C)c2c1Oc1cccc(C(F)(F)F)c1</smiles>

1<smiles>COc1cc(NCc2cc3ccccc3o2)c2nccc(C)c2c1Oc1cccc(C(F)(F)F)c1</smiles><smiles>COc1cc(NC(=O)c2ccco2)c2nccc(C)c2c1Oc1cccc(C(F)(F)F)c1</smiles>

9<smiles>COc1cc(NCc2nccs2)c2nccc(C)c2c1Oc1cccc(C(F)(F)F)c1</smiles>

2<smiles>COc1cc(NCc2ccc(-c3ccccc3)s2)c2nccc(C)c2c1Oc1cccc(C(F)(F)F)c1</smiles>

6<smiles>[R]c1cccc(Oc2c(OC)cc(NCCCN)c3nccc(C)c23)c1</smiles>

$11: R^{1}=F$

$13: R^{1}=H$<smiles>[R]Oc1cc(NCc2ccc(O)cc2)c2nccc(C)c2c1Oc1cccc([R])c1</smiles>

3: $\mathrm{R}^{1}=\mathrm{CF}_{3} ; \mathrm{R}^{2}=\mathrm{Me}$

10: $\mathrm{R}^{1}=\mathrm{CF}_{3} ; \mathrm{R}^{2}=\mathrm{H}$

12: $R^{1}=F ; R^{2}=M e$

$14: R^{1}=H ; R^{2}=M e$<smiles>COc1cc(NCc2cccc3cccnc23)c2nccc(C)c2c1Oc1cccc(C(F)(F)F)c1</smiles><smiles>COc1cc(NCCC(N)=O)c2nccc(C)c2c1Oc1cccc(C(F)(F)F)c1</smiles>

8<smiles>COc1ccc2nccc(C)c2c1</smiles><smiles>NCc1ccc(O)cc1</smiles>

16

From an initial screening of synthesized substituted quinoline compounds using MC65 cells, we found that compound $\mathbf{1}$ possesses strong neuronal cell protective activity (vide infra). Hence, its analogs, quinolines 2 - 16 possessing different heterocycle- or arene-appended methylamino moiety at $\mathrm{C} 8$, different $\mathrm{C} 5$ aryloxy moieties, no $\mathrm{C} 5$ aryloxy group, and C6 hydroxyl function, were synthesized. A reductive amination reaction was used to assemble 
compounds $2-7$ via the coupling of amine $17^{21}$ and aldehydes $18-23$ with sodium cyanoborohydride in methanol in good to moderate yields (Scheme 1). Aldehydes $\mathbf{1 8}-\mathbf{2 2}$ were obtained from commercial sources while 23 was prepared as reported. ${ }^{22}$ Compounds $2-7$ contain different heterocycle- or arene-appended methylamino functions at C8, which depart from that of compound 1 .

Scheme 1. Synthesis of Compounds 2 - 7 via reductive amination reactions.<smiles>COc1cc(N)c2nccc(C)c2c1Oc1cccc(C(F)(F)F)c1</smiles>

17

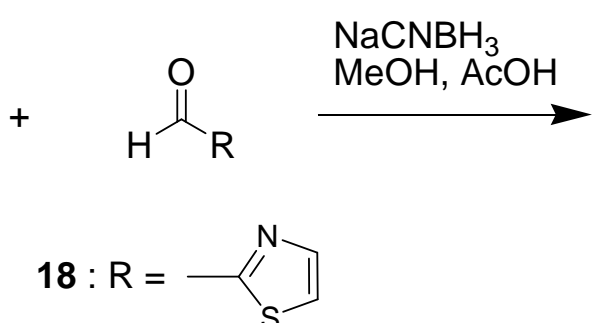

19<smiles>[R]Cc1ccc(O)cc1</smiles><smiles>[R]Oc1cc(C#[R]OC)cc(OC)c1O</smiles>

$21: \mathrm{R}=$<smiles>Cc1cc2ccccc2o1</smiles>

$22: \mathrm{R}=$<smiles>Cc1ccc(-c2ccccc2)s1</smiles><smiles>[R3]#Cc1cccc2cccnc12</smiles><smiles>[R]CNc1cc(OC)c(Oc2cccc(C(F)(F)F)c2)c2c(C)ccnc12</smiles>

2 (72\% yield)

3 (82\% yield)

4 (75\% yield)

5 (65\% yield)

6 (78\% yield)

7 (76\% yield)

The C8 appended 3-aminopropylamine function of compound $\mathbf{1}$ was also modified by introducing a 3-amino-3-oxopropylamine moiety at $\mathrm{C} 8$, i.e., compound $\mathbf{8}$, or varied by a 2 furanylamide group, compound $\mathbf{9}$. Compound 8 was readily synthesized from a Michael addition reaction of amine 17 with acrylamide in acetonitrile in a sealed tube at $120^{\circ} \mathrm{C}$ in a $57 \%$ 
yield, and amide 9 was prepared in a 75\% yield from the acylation reaction of amine 17 with 2furancarbonyl chloride (24) (Scheme 2). Among the tested quinolines using MC65 cell assays, compounds $\mathbf{1}$ and $\mathbf{3}$ appear to be the most active quinolines (vide infra), hence the C6-hydroxyl analog of $\mathbf{3}$ and molecules possessing different substituents at C5, i.e., compounds $\mathbf{1 0}$ - 16, were examined. The C6-methyl ether group of $\mathbf{1 7}$ was removed with boron tribromide in dichloromethane, and the resulting quinoline 25 condensed with aldehyde 19 to give hydroxyl analog 10 in a $52 \%$ yield.

Scheme 2. Synthesis of Quinolines 8 - 10.

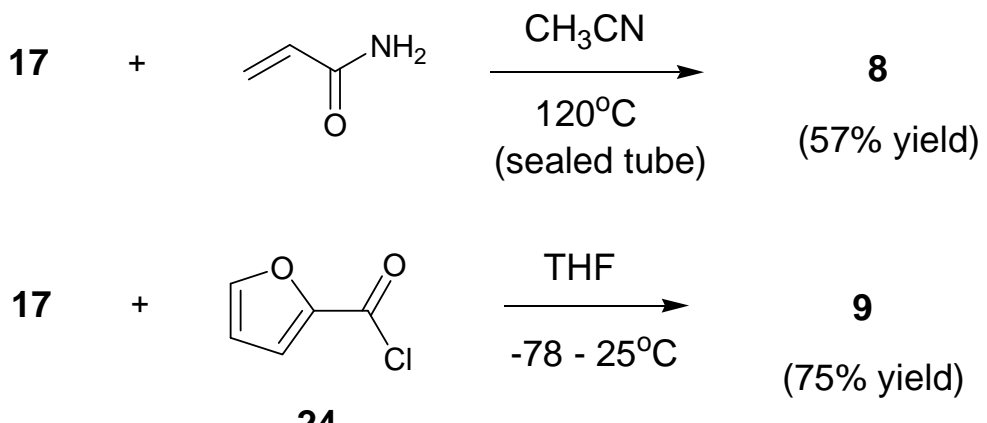

24

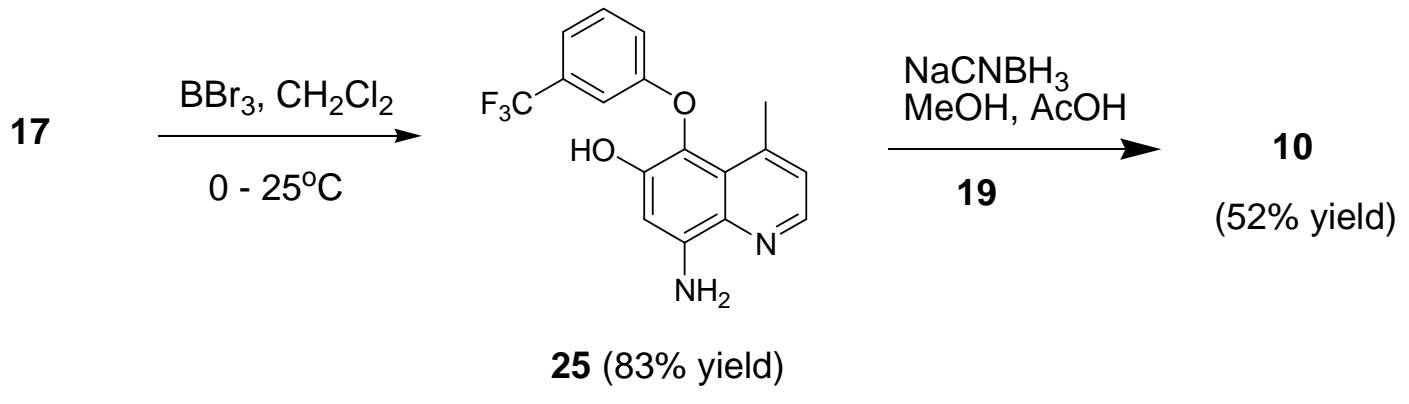

C5-Aryloxy analogs of $\mathbf{1}$ such as compounds $\mathbf{1 1}$ and $\mathbf{1 3}$ were obtained from a sequence of reactions starting from bromide 26 (Scheme 3). ${ }^{21}$ Hence, nucleophilic aromatic substitution reactions of bromide 26 with potassium 3-fluorophenoxide (27) and potassium phenoxide (28) separately in DMF gave aryl ether 29 and 30 in 65 and 80\% yield, respectively (Scheme 3). 
Removal of the acetyl protecting group of $\mathbf{2 9}$ and $\mathbf{3 0}$ with $\mathrm{HCl}$ in ethanol followed by ring closing reactions with 3-buten-2-one and arsenic acid in phosphoric acid provided quinolines 31 and 32 in 35 and $45 \%$ yield, respectively. Reduction of the nitro function of $\mathbf{3 1}$ and $\mathbf{3 2}$ separately with iron in acetic acid followed by alkylation of the resulting 8 -aminoquinolines 33 and 34 with 3-iodopropylphthalimide, ${ }^{21}$ and deprotection with hydrazine afforded $\mathbf{1 1}$ and 13, respectively. Condensation of amines 33 and 34 separately with 4-hydroxybenzaldehyde and sodium cyanoborohyride furnished amines 12 and $\mathbf{1 4}$, respectively.

Scheme 3. Synthesis of Quinolines 11 - 14.
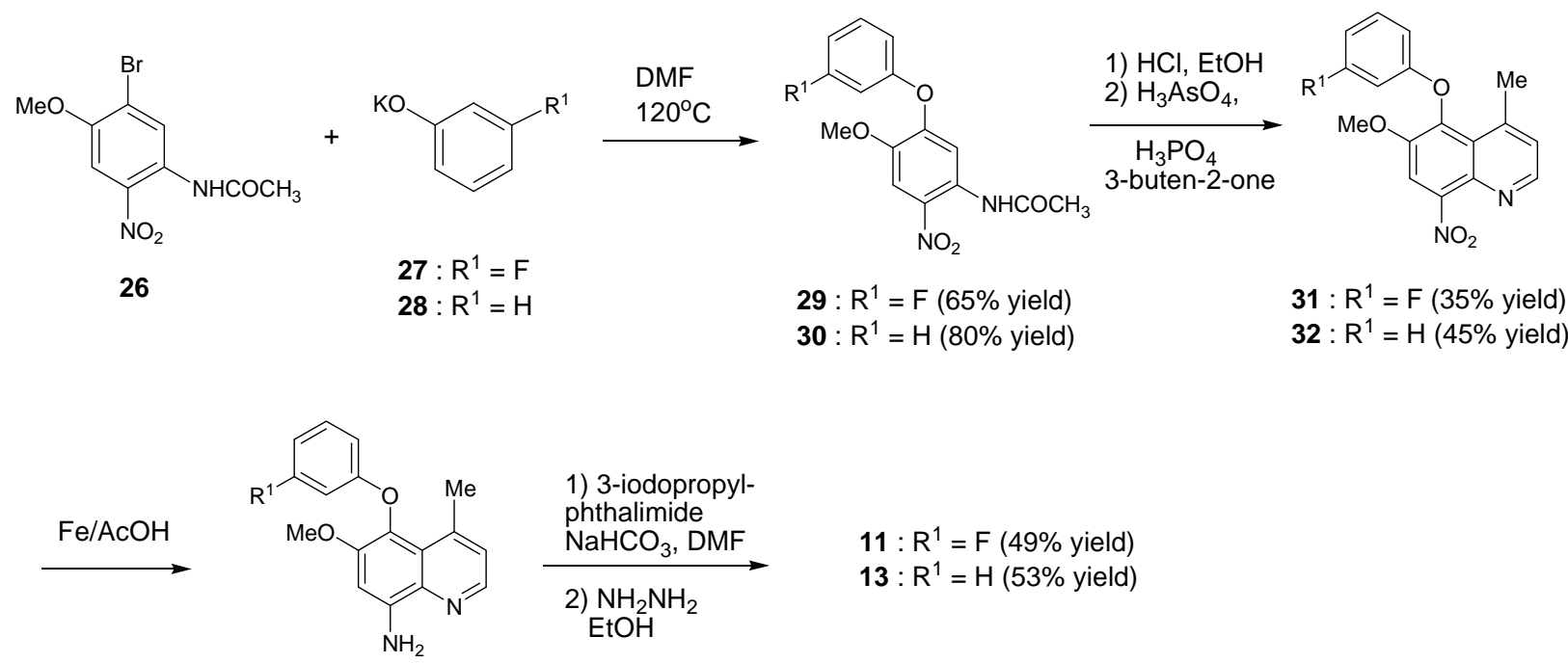

$33: R^{1}=F(92 \%$ yield $)$

$34: R^{1}=H(92 \%$ yield $)$

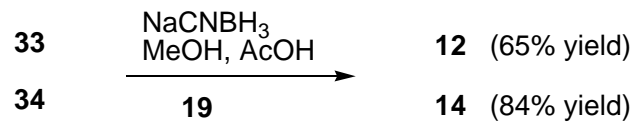

Quinolines without C5 aryloxy function, $\mathbf{1 5}^{23}$ and $\mathbf{1 6}$, were similarly synthesized from the ring closing reaction of 4-amino-3-nitroanisole with 3-buten-2-one followed by the reduction with iron in acetic acid to give amine $35^{24}$ in an $85 \%$ overall yield (Scheme 4). Alkylation of amine 35 with 3-iodopropylphthalimide followed by the treatment of hydrazine gave $\mathrm{C} 5-\mathrm{H}$ 
analog 15, and reductive amination of amine 35 with aldehyde 19 and sodium cyanoborohydride afforded derivative 16.

Scheme 4. Synthesis of Quinolines 15 and 16.

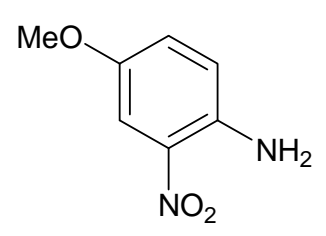

1) $\mathrm{H}_{3} \mathrm{AsO}_{4}$,

$\mathrm{H}_{3} \mathrm{PO}_{4}$

$\underset{\text { 3-buten-2-one }}{\longrightarrow}$

2) $\mathrm{Fe} / \mathrm{AcOH}$

(85\% yield)

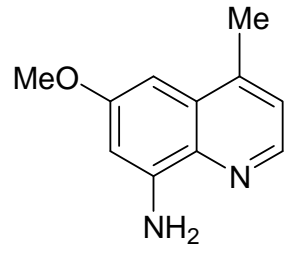

35

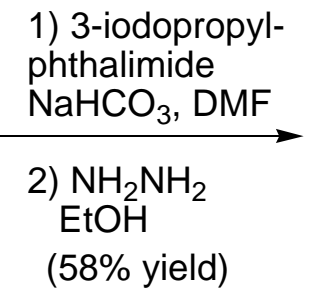

(58\% yield)

35

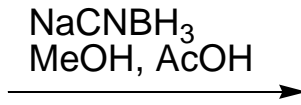

19

(73\% yield)

MC65 cell line was used as a screen to search for neural protective compounds against

cell death induced by oligomeric $A \beta$ peptides. ${ }^{13-15}$ On day three, the induction of S $\beta C$ gene (in the absence of tetracycline) in MC65 cells leads to the production of the C99 fragment of amyloid precursor protein and subsequently to $A \beta$ peptides from the proteolysis by $\gamma$-secretase, resulting in cell death. Compounds that protect cell from death likely possess anti-A $\beta$ property. An addition of tetracycline, an antioxidant, to the media of MC65 cells suppresses the production of C99 fragment and cells survive. Consequently, toxicity of the compound to MC65 cells is determined. Table 1 tabulates the $\mathrm{EC}_{50}$ (median effective concentration) and $\mathrm{TC}_{50}$ (median toxic concentration) values of quinoline compounds, $\mathbf{1}-\mathbf{1 6}$. From our initial screen of compounds $\mathbf{1}-$ $\mathbf{9}$ having various functionalities at $\mathrm{C} 8$ of the quinoline, compounds $\mathbf{1}$ and $\mathbf{3}$ showed the greatest activities with $\mathrm{EC}_{50}$ values of 0.15 and $0.12 \mu \mathrm{M}$, respectively. Results suggest that the presence of a 3-aminopropylamine or p-hydroxyphenylmethylamine function leads to higher bioactivity. 
Modifications at C5 and C6 were therefore carried out by keeping appended C8 with either 3aminopropylamine or $p$-hydroxyphenylmethylamine, such as compounds 10 - 16. Among these seven derivatives, C6-hydroxy derivative $\mathbf{1 0}$ and C5-phenoxy $\mathbf{1 3}$ are the most active analogs with $\mathrm{EC}_{50}$ values of 0.30 and $0.42 \mu \mathrm{M}$, respectively, while other analogs having $\mathrm{EC}_{50}$ values range from 0.53 to $17.6 \mu \mathrm{M}$. The results indicate that compound 3 is a suitable candidate for mechanistic investigation.

Table 1. $\mathrm{EC}_{50}$ and $\mathrm{TC}_{50}$ values of Compounds $\mathbf{1}$ - $\mathbf{1 6}$ from MC65 cell protection assays. ${ }^{25}$ Values are expressed in mean \pm standard deviation.

\begin{tabular}{|c|c|c|c|c|c|}
\hline Compound & $\mathrm{EC}_{50}(\mu \mathrm{M})$ & $\mathrm{TC}_{50}(\mu \mathrm{M})$ & Compound & $\mathrm{EC}_{50}(\mu \mathrm{M})$ & $\mathrm{TC}_{50}(\mu \mathrm{M})$ \\
\hline $\mathbf{1}$ & $0.15 \pm 0.02$ & $2.10 \pm 0.03$ & $\mathbf{9}$ & $3.47 \pm 0.32$ & $>50$ \\
\hline $\mathbf{2}$ & $2.39 \pm 0.06$ & $20.32 \pm 1.22$ & $\mathbf{1 0}$ & $0.30 \pm 0.01$ & $3.31 \pm 0.30$ \\
\hline $\mathbf{3}$ & $0.12 \pm 0.01$ & $1.38 \pm 0.08$ & $\mathbf{1 1}$ & $0.60 \pm 0.02$ & $7.28 \pm 0.26$ \\
\hline $\mathbf{4}$ & $0.48 \pm 0.03$ & $2.91 \pm 0.15$ & $\mathbf{1 2}$ & $0.70 \pm 0.08$ & $2.60 \pm 0.20$ \\
\hline $\mathbf{5}$ & $0.46 \pm 0.11$ & $>50$ & $\mathbf{1 3}$ & $0.42 \pm 0.01$ & $8.16 \pm 0.01$ \\
\hline $\mathbf{6}$ & $0.39 \pm 0.02$ & $14.50 \pm 1.68$ & $\mathbf{1 4}$ & $0.53 \pm 0.01$ & $4.01 \pm 0.38$ \\
\hline $\mathbf{7}$ & $0.19 \pm 0.02$ & $>50$ & $\mathbf{1 5}$ & $17.62 \pm 0.37$ & $>50$ \\
\hline $\mathbf{8}$ & $0.50 \pm 0.02$ & $>50$ & $\mathbf{1 6}$ & $2.62 \pm 0.15$ & $20.54 \pm 0.21$ \\
\hline
\end{tabular}

Hyperphosphorylation of tau proteins by GSK-3 $\beta$ leads to the formation of neurofibrillary tangles, ${ }^{16-20}$ hence inhibition of GSK-3 $\beta$ by selected quinoline compounds was conducted in search of possible mechanism of action. Protein kinase C (PKC) mediates the function of other proteins in signal-transduction pathways of different cell types through the phosphorylation of hydroxyl functions of serine and threonine residues of these proteins. ${ }^{26}$ In particular, phosphorylation of potent activators of transcription would increase oncogene expressions resulting in the promotion of cancer progression. ${ }^{27}$ Therefore, the inhibition of PKC 
was also carried out. Table 2 summarizes results of the inhibition of GSK3 $\beta$ and PKC and the selectivity index (SI) by selected quinolines using the respective GSK-3 $\beta$ kinase assay and PepTag ${ }^{\circledR}$ non-radioactive PKC assay kits (both obtained from Promega Co.). Interestingly, the gap junction enhancer compound $\mathbf{1}^{21}$ inhibited PKC with half maximum inhibitory concentration $\left(\mathrm{IC}_{50}\right)$ value of $35 \mathrm{nM}$ but does not inhibit GSK-3 $\beta$ up to $1 \mathrm{mM}$. A similar finding is observed with quinoline 7 except with much higher $\mathrm{IC}_{50}$ value of $400 \mu \mathrm{M}$ against PKC. Quinolines 3 and $\mathbf{1 0}$ on the other hand show excellent selectivity for GSK-3 $\beta$. The $\mathrm{IC}_{50}$ values of $\mathbf{3}$ and $\mathbf{1 0}$ against GSK-3 $\beta$ are $35 \mathrm{nM}$ and $158 \mathrm{nM}$, respectively, while the values against PKC are 240 and $750 \mu \mathrm{M}$, respectively. The SI values of these two compounds are 6,857 and 4,747, respectively, suggesting kinase specificity. Under similar assay conditions, staurosporine ${ }^{26,28}$ show potent but nondiscriminating inhibitions with $\mathrm{IC}_{50}$ values against $\mathrm{GSK}-3 \beta$ and $\mathrm{PKC}$ of 38 and $33 \mathrm{nM}$.

Table 2. Enzyme inhibitory activities of GSK-3 $\beta$ and PKC by selected quinoline compounds and selectivity index (SI) values. ${ }^{25}$ Values are expressed in mean \pm standard deviation.

\begin{tabular}{|c|c|c|c|}
\hline Compounds & IC 50 value, & IC 50 value, & SI \\
& GSK-3 $\beta$ & PKC & $\left(\right.$ PKC IC $\left._{50} / \mathrm{GSK} 3 \beta \mathrm{IC}_{50}\right)$ \\
\hline $\mathbf{1}$ & $>1 \mathrm{mM}$ & $35 \pm 8 \mathrm{nM}$ & $<3.5 \times 10^{-5}$ \\
\hline $\mathbf{3}$ & $35 \pm 6.36 \mathrm{nM}$ & $240 \pm 21.2 \mu \mathrm{M}$ & 6,857 \\
\hline $\mathbf{7}$ & $>1 \mathrm{mM}$ & $400 \pm 13.7 \mu \mathrm{M}$ & $<0.4$ \\
\hline $\mathbf{1 0}$ & $158 \pm 19.1 \mathrm{nM}$ & $750 \pm 9.3 \mu \mathrm{M}$ & 4,747 \\
\hline Staurosporine & $38 \pm 7 \mathrm{nM}$ & $33 \pm 5 \mathrm{nM}$ & 0.87 \\
\hline
\end{tabular}


Compound 3 possesses strong neuronal cell protection and inhibitory activity against GSK-3 $\beta$, therefore, to examine whether 3 is suitable for future in vivo efficacy study, the distribution of $\mathbf{3}$ in various tissues and possible toxic effects in the locomotors and inhibition of liver enzymes activities in mice were carried out. The amounts of $\mathbf{3}$ in various tissues were quantified by following a reported procedure, ${ }^{29}$ and results are summarized in Table 3 from an oral gavage administration each day of $5 \mathrm{mg} / \mathrm{Kg}$ body weight of CD1 mice of 3 (two untreated and four treated mice were used) for 75 days. The amounts of $\mathbf{3}$ in various organs and plasma remained in low concentrations after 75 days and appeared to accumulate in brain and pancreases in greater amounts than other tissues and plasma.

Table 3. Distribution of compound 3 in various tissues and plasma from an oral route administration of 3 into CD1 mice with $5 \mathrm{mg} / \mathrm{Kg}$ body weight daily for 75 days $(\mathrm{n}=4)$. Values are expressed in mean \pm standard deviation, and ND is not detectable.

\begin{tabular}{|c|c|c|c|c|c|c|}
\hline Tissues & Brain & Pancreases & Liver & Kidney & Lung & Plasma \\
\hline $\begin{array}{c}\text { Concentration } \\
\text { of } 3(\mu \mathrm{M})\end{array}$ & $24.4 \pm 6.4$ & $26.5 \pm 6.6$ & $7.1 \pm 0.6$ & $16.1 \pm 2.1$ & ND & $4.5 \pm 0.3$ \\
\hline
\end{tabular}

After 75 days of treatment, behavioral activity was monitored using Versamax (AccuScan Instruments Inc., Columbus, OH, USA), where readings were taken before and after administration of 3 . The Versamax chamber is ventilated and equipped with infrared sensors along the side wall. Prior to the reading, each mouse was left in the chamber for 15 minutes for acclimatization. Administration of $\mathbf{3}$ for 75 days did not showed any effect on the overall locomotors activity of mice in terms of clockwise or counter-clockwise activity, total covered distance, rest time, vertical activity, and horizontal activity when compared with control mice 
(Figure 2). Results suggest that chronic administration of $\mathbf{3}$ did not have any behavioral side effects in mice.
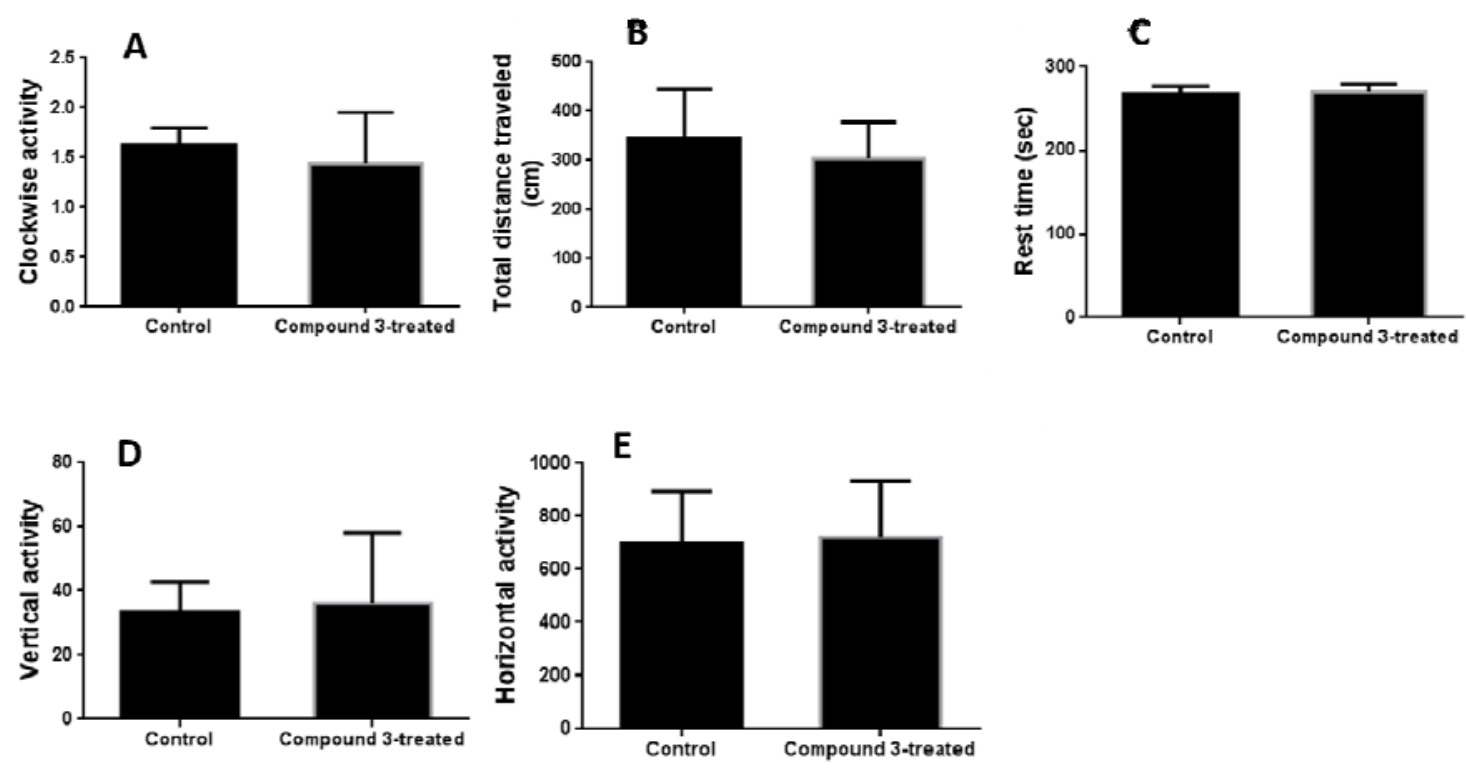

Figure 2. Effect of chronic administration of compound 3 on the locomotors activity of mice. Control and compound $3(5 \mathrm{mg} / \mathrm{Kg}$ daily by oral gavage for 75 days) treated mice were acclimatized for 15 min inside Versamax chamber followed by monitoring their movements. (A) Clockwise revolution, (B) total distance covered, (C) rest time, (D) vertical activity, and (E) horizontal activity.

Possible liver toxicity was examined by measuring enzymatic activities of liver transaminases, aspartate aminotransferase (AST) and alanine transaminase (ALT), biomarkers of toxicity. Mice were sacrificed on day 75 after daily oral administration of 3 . Blood was collected from heart by using syringe containing heparin to prevent clotting. Plasma was separated immediately to prevent hemolysis by centrifugation at $10,000 \mathrm{xg}$ for 5 minutes. The enzymatic activities of AST and ALT were determined using a commercially available kit 
(Pointe Scientific, Inc, Canton, MI, USA), according to manufacturer's instructions. To evaluate the toxicity of $\mathbf{3}$ upon chronic administration, ALT and AST enzyme activities were evaluated in the plasma of control and treated mice, and results are depicted in Figure 3. No significant difference in the activities of ALT and AST was observed between control and treated mice suggesting that $\mathbf{3}$ is relatively safe for long-term use.
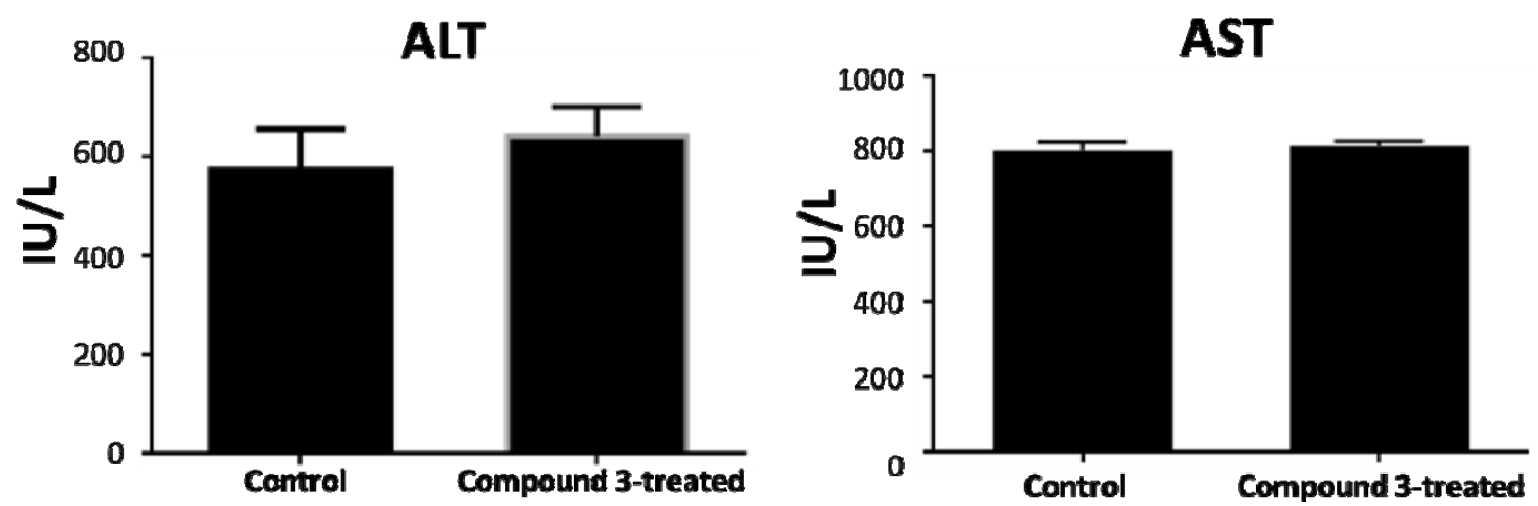

Figure 3: Effect of compound 3 on the biochemical markers of toxicity. After 75 days of daily administration of $3(5 \mathrm{mg} / \mathrm{kg})$ by oral gavage, mice were sacrificed and plasma was separated from the blood of control and treated mice and evaluated for ALT and AST enzymatic activities.

In summary, a number of neural protective quinoline molecules were synthesized and evaluated in cells and enzyme assays. Compound $\mathbf{3}$ and its C6-hydroxyl analog $\mathbf{1 0}$ were the most potent molecules and they inhibit GSK-3 $\beta$ selectively in nanomolar concentrations. Compound 3 distributed mainly to the brain and pancreases in mice after administration of 5 $\mathrm{mg} / \mathrm{Kg}$ daily by oral route over 75 days and showed no apparent toxicity through the examination of locomotors activity and liver transaminases. Hence, the molecule appears to be safe for long-term study in AD mouse model. The synthetic procedure leading to this class of 
neural protective compound is general and further structural optimization is possible for future drug discovery and development.

\section{Acknowledgement}

Research reported in this presentation was supported by the National Institute of General Medical Sciences of the National Institutes of Health under Award Number P20GM103418 and Johnson Cancer Center, Kansas State University (D.H.H.) and R01 grant CA129038 awarded by the National Cancer Institute, NIH (S.K.S.). The content is solely the responsibility of the authors and does not necessarily represent the official views of the National Institutes of Health. $\mathrm{RE}$ and JN were supported by The Council of Higher Education of Turkey and Summer Undergraduate Research Opportunity Program of Kansas State University, respectively. We thank Keshar Prasain for obtaining initial PKC data of compound $\mathbf{1 .}$

\section{Supplementary data}

Supplementary data (synthetic procedure, chemical analysis data, enzyme assays, cell assays, in vivo toxicity study, and quantification of tested compound in various tissues) associated with this article can be found, in the online version, at http://dx.doi.org

\section{References and notes}

1. Mangialasche, F.; Solomon, A.; Winblad, B.; Mecocci, P.; Kivipelto, M. Lancet Neurol. 2010, 9, 702 .

2. Palmer, A. M. Trends in Pharmacol. Sci. 2011, 32, 141. 
3. Salomone, S.; Caraci, F.; Leggio, G. M.; Fedotova, J.; Drago, F. Br. J. Clin. Pharmacol. 2012, 73, 504 .

4. Chu J.; Li, J. -G.; Pratico, D. Plos One 2013, 8, e70991, 8 pages.

5. Pierce, A.; Podlutskaya, N.; Halloran, J. J.; Hussong, S. A.; Lin, P. -Y.; Burbank, R.; Hart, M. J.; Galvan, V. J. Neurochem. 2013, 124, 880.

6. Ozcelik, S.; Fraser, G.; Castets, P.; Schaeffer, V.; Skachokova, Z.; Breu, K.; Clavaguera, F.; Sinnreich, M.; Kappos, L.; Goedert, M.; Tolnay, M.; Winkler, D. T. Plos One 2013, 8, e62459, 7 pages.

7. Ma, Q. -L.; Zuo, X.; Yang, F.; Ubeda, O.; Gant, D. J.; Alaverdyan, M.; Teng, E.; Hu, S.; Chen, P. -P.; Maiti, P.; Teter, B.; Cole, G. M.; Frautschy, S. A. J. Biol. Chem. 2013, 288, 4056.

8. Herculano, B.; Tamura, M.; Ohba, A.; Shimatani, M.; Kutsuna, N.; Hisatsune, T. J. Alz. Dis. 2013, 33, 983.

9. Lilja, A. M.; Luo, Y.; Yu, Q. -S.; Rojdner, J.; Li, Y.; Marini, A. M.; Marutle, A.; Nordberg, A.; Greig, N. H. Plos One 2013, 8, e54887, 10 pages.

10. Guo, C.; Wang, T.; Zheng, W.; Shan, Z. -Y.; Teng, W. -P.; Wang, Z. -Y. Neurobiol. Aging 2013, 34, 562 .

11. Zhao, L.; Wang, J. -L.; Liu, R.; Li, X. -X.; Li, J. -F.; Zhang, L. Molecules 2013, 18, 9949.

12. Zeng, Y.; Wang, Y. -J.; Zhou, X. -F.; Yueqin, Z. Front. Neurol. 2014, 5, 69.

13. Pokhrel, L.; Maezawa, I.; Nguyen, T. D. T.; Chang, K. -O.; Jin, L. -W.; Hua, D. H. J. Med. Chem. 2012, 55, 8969.

14. Hong, H. S.; Rana, S.; Barrigan, L.; Shi, A.; Jin, L. -W.; Hua, D. H. J. Neurochem. 2009, 108, 1097. 
15. Maezawa, I.; Hong, H. S.; Wu, H. C.; Battina, S. K.; Rana, S.; Iwamoto, T.; Radke, G. A.; Pettersson, E.; Martin, G. M.; Hua, D. H.; Jin, L. -W. J. Neurochem. 2006, 98, 57.

16. Flaherty, D. B.; Soria, J. P.; Tomasiewicz, H. G.; Wood, J. G. J. Neurosci. Res. 2000, 62, 463.

17. Spittaels, K.; Van Den Haute, C.; Van Dorpe, J.; Geerts, H.; Mercken, M.; Bruynseels, K. Lasrado, R.; Vandezande, K.; Laenen, I.; Van Lint, J.; Vandenheede, J.; Moechars, D.; Loos, R.; Van Leuven, F. J. Biol. Chem. 2000, 275, 41340.

18. Eldar-Finkelman, H.; Martinez, A. Front. Mol. Neurosci. 2011, 4, 1.

19. Small, S. A.; Duff, K. Neuron 2008, 60, 534.

20. Phukan, S.; Babu, V. S.; Kannoji, A.; Hariharan, R.; Balaji, V. N. British J. Pharm. 2010, $160,1$.

21. Shi, A.; Nguyen, T. A.; Battina, S. K.; Rana, S.; Takemoto, D. J.; Chiang, P. K.; Hua, D. H. Bioorg. \& Med. Chem. Lett. 2008, 18, 3364.

22. Pokhrel, L.; Kim, Y.; Nguyen, T. D. T.; Prior, A. M.; Lu, J.; Chang, K. -O.; Hua, D. H. Bioorg. \& Med. Chem. Lett. 2012, 22, 3480.

23. Schmidt, L. H. Antimicrob. Agents Chemother. 1983, 24, 615.

24. Campbell, K. N.; Sommers, A. H.; Kerwin, J. F.; Campbell, B. K. J. Am. Chem. Soc. 1946, $68,1556$.

25. Each experiment was performed in triplicate and standard deviation was calculated.

26. Wilkinson, S. E.; Parker, P. J.; Nixon, J. S. Biochem. J. 1993, 294, 335.

27. Yamasaki, T.; Takahashi, A.; Pan, J.; Yamaguchi, N.; Yokoyama, K. K. J. Biol. Chem. 2009, $284,8567$. 
28. Bertrand, J. A.; Thieffine, S.; Vulpetti, A.; Cristiani, C.; Valsasina, B.; Knapp, S.; Kalisz, H. M.; Flocco, M. J. Mol. Biol. 2003 333, 393.

29. Shishido, S. N.; Prasain, K.; Beck, A.; Nguyen, T. D. T.; Hua, D. H.; Nguyen, T. A. Plos One 2013, 8, e67174; 13 pages. 